\title{
Precipitation behavior and mechanical properties of a hot rolled Ti-bearing
}

\section{dual phase steel}

\author{
Cheng-Ning Li $^{1 *}$, Xiao-lei Li ${ }^{1,2}$, Guo Yuan ${ }^{1 *}$, R.D. K. Misra ${ }^{3}$, Jian Kang ${ }^{1}$, Guo-Dong Wang ${ }^{1}$ \\ ${ }^{1}$ State Key Laboratory of Rolling and Automation, Northeastern University. \\ P. O. Box. 105, No. 11, Lane 3, Wenhua Road, Heping District, Shenyang 110819, China. \\ 2 Shougang Qian'an Iron and Steel Co., Ltd., Qian'an 064404, Hebei, China. \\ ${ }^{3}$ Laboratory for Excellence in Advanced Steel Research, Department of Metallurgical, Materials and \\ Biomedical Engineering, University of Texas at El Paso, TX 79912, USA.
}

\begin{abstract}
$\underline{\text { Abstract }}$
We have studied here the microstructure, precipitate evolution and mechanical properties in a Fe-Mn-Cr-Ti dual phase steel processed by thermo-mechanical control processing. When the deformed austenite was treated in the temperature range of $640-760{ }^{\circ} \mathrm{C}$, the microstructure consisted of ferrite and 7-80\% martensite. Both random and interphase precipitation of nanoscale TiC particles occurred in the ferrite matrix. With decrease in temperature, the average size of precipitates was reduced from $5.4 \mathrm{~nm}$ to $2.2 \mathrm{~nm}$, and the morphology of interphase precipitation was altered from curved to planar because of the change in the mechanism of $\mathrm{TiC}$ interphase precipitation. Hot rolling inhibited interphase precipitation but promoted precipitation on dislocations. Given that the ferrite matrix was significantly strengthened by nanoscale TiC particles, the hardness difference between the ferrite matrix and martensite was significantly decreased, and the strength of hot rolled Ti-bearing dual phase steels was less dependent on the martensite content compared to the conventional dual phase steels. The strength of hot rolled Ti-bearing dual phase steels was derived from a number of strengthening mechanisms, namely phase transformation, precipitation and grain refinement strengthening.
\end{abstract}

Keywords: Hot rolled Ti-bearing dual phase steel; Nanoscale TiC particle; Precipitation strengthening; Thermo-mechanical control processing, Phase transformation.

*Corresponding author.

E-mail address: yuanguoneu@163.com (G. Yuan); licn09@126.com (C.N. Li). 


\section{Introduction}

High strength steels are widely used for structural applications in the automotive and mechanical sector [1]. In the last two decades, low carbon high strength low alloy (HSLA) steels with high toughness have been successfully processed to obtain strengthening through grain refinement and precipitation [2-6]. However, HSLA steels have disadvantages of high yield ratio and higher cost. Dual phase steels (DP steels) are one class of advanced high strength steels (AHSS) that have the low yield ratio, excellent combination of strength and ductility, and lower cost [7-9]. The low yield strength and good ductility of dual phase steels is associated with the soft and ductile ferrite matrix, while the high tensile strength is primarily governed by the hard martensite [8-10]. However, it is difficult to further enhance the strength of dual phase steels only via martensite phase because the volume fraction of martensite is generally limited to less than $\sim 30 \%$ to ensure good ductility. On the other hand, the large difference in hardness between ferrite and martensite in conventional dual phase steels is responsible for low hole expansion $[6,11,12]$.

Considering the disadvantages of low carbon HSLA steels and conventional DP steels, a class of hot rolled dual phase steels strengthened by phase transformation strengthening and precipitation strengthening is being considered [13-16]. These dual phase steels are based on the concept of strengthening the ferrite matrix through nanoscale TiC particles. The nanoscale precipitates effectively strengthen the ferrite matrix, enhance the strength of the dual phase steels and reduce the difference in hardness between ferrite and martensite phase. To develop hot rolled steels that comprise of ferrite matrix with TiC particles and dispersed martensite islands, 0.1 wt.\% Ti was added and Si content was increased to $~ 1.5$ wt. \% to match the nose of TiC precipitation with that of ferrite transformation and enhance the hardenability of untransformed austenite. Murakami et al. studied the effects of rolling conditions on precipitation in $\mathrm{C}-\mathrm{Si}-\mathrm{Mn}$-Ti dual phase steel and found that the fatigue limit was maximized with the average $\mathrm{TiC}$ size of $\sim 7 \mathrm{~nm}$ [15]. $\mathrm{Hu}$ et al. obtained a tensile strength of $780 \mathrm{MPa}$ $0.08 \mathrm{C}-1.5 \mathrm{Si}-1.7 \mathrm{Mn}-0.1 \mathrm{Ti}$ dual phase steel and indicated that the yield strength of the steel was high because of the TiC precipitation and solid solution strengthening led by silicon [16].

Compared to the cold rolled-annealing process, the thermo-mechanical control processing (TMCP) does not required additional heat treatment after coiling. Thus, austenite-to-ferrite transformation, precipitation in the ferrite matrix, and austenite-to-martensite transformation in hot rolled dual phase steels need to be accomplished on the run-out table after hot rolling. The martensite phase can be obtained on hot rolling line 
through the fast cooling to below $M_{S}$ before coiling [17,18]. In this regard, ferrite transformation and its relationship with the precipitation behavior are critical to develop dual phase steels strengthened by nanoscale TiC particles. On the other hand, the Ti-containing dual phase steels reported previously were characterized by high Si content, which renders poor surface quality.

In the study described here, a hot rolled Ti-bearing dual phase steel with low Si content was evaluated. A series of TMCP simulation were adopted to elucidate the effect of ferrite transformation temperature on microstructural evolution and precipitation behavior on the run-out table. TMCP was carried out with the objective of obtaining a hot rolled dual phase steel consisting of ferrite matrix with nanoscale TiC particles and dispersed martensite islands. Furthermore, the precipitation behavior and its effects on mechanical properties were discussed in detail to obtain fundamental understanding of precipitation mechanism and mechanical properties in hot rolled Ti-bearing dual phase steels with low Si content.

\section{Experimental procedure}

\subsection{TMCP simulation}

The chemical composition of the experimental steel in wt.\% was $0.06 \mathrm{C}, 0.25 \mathrm{Si}, 1.50 \mathrm{Mn}, 0.50 \mathrm{Cr}, 0.10$ Ti, $0.02 \mathrm{Al}, 0.0028 \mathrm{P}, 0.0016 \mathrm{~S}$ and $0.004 \mathrm{~N}$. The steel was melted in a $160 \mathrm{~kg}$ vacuum induction furnace and cast into ingots. The ingots were subsequently forged into square billets of $70 \mathrm{~mm} \times 90 \mathrm{~mm} \times 100 \mathrm{~mm}$. The billets were heated to $1250^{\circ} \mathrm{C}$ for $2 \mathrm{~h}$ and then hot rolled to $12 \mathrm{~mm}$ thickness on $\Phi 450 \mathrm{~mm}$ two-high rolling. Cylindrical samples of $\Phi 8 \mathrm{~mm} \times 15 \mathrm{~mm}$ for thermal simulation experiments were machined from the hot rolled plates along the rolling direction. MMS-300 thermo-mechanical simulator was used to simulate the TMCP, and the schematic diagram is presented in Fig. 1a. The specimens were heated to $1250{ }^{\circ} \mathrm{C}$ (above $\alpha-\gamma$ complete transformation temperature) for $180 \mathrm{~s}$ to obtain the full austenite with abundant dissolved alloying elements. Next, the specimens were cooled to $880{ }^{\circ} \mathrm{C}$ at a cooling rate of $10^{\circ} \mathrm{C} / \mathrm{s}$, held for $20 \mathrm{~s}$ to eliminate the temperature gradient, and deformed in compression to $\sim 50 \%$ strain at a strain rate of $5 / \mathrm{s}$. The austenite-ferrite start transformation temperature $\left(\mathrm{A}_{\mathrm{r} 3}\right)$ of the experimental steel was estimated at $\sim 762{ }^{\circ} \mathrm{C}$ by $\mathrm{A}_{\mathrm{r} 3}=910-310 C-80 \mathrm{Mn}-20 \mathrm{Cu}-55 \mathrm{Ni}-80 \mathrm{Mo}-0.35(h-8)$ [19], where $h$ is the plate thickness $(\mathrm{mm})$, and in our case is the specimen diameter of $8 \mathrm{~mm}$. Therefore, after deformation, the specimens were cooled at a rate of $30{ }^{\circ} \mathrm{C} / \mathrm{s}$ to $760,740,720,700,680,660$ and $640{ }^{\circ} \mathrm{C}$, respectively, and held for $300 \mathrm{~s}$ in order to obtain ferrite. Finally, 
the specimens were rapidly cooled to room temperature at a cooling rate of $80{ }^{\circ} \mathrm{C} / \mathrm{s}$ to promote martensitic transformation.

\subsection{TMCP practice}

The TMCP practice was carried out on two-high $\Phi 450 \mathrm{~mm}$ experimental hot rolling mill equipped with water cooling system developed in our laboratory, and the schematic diagram is presented in Fig. 1b. The plates of $70 \mathrm{~mm}$ thickness were reheated to $1250{ }^{\circ} \mathrm{C}$ for $1 \mathrm{~h}$ and hot rolled to $5 \mathrm{~mm}$ thick strips via nine passes. The hot rolling was initiated at $1150{ }^{\circ} \mathrm{C}$ and finished at $880{ }^{\circ} \mathrm{C}$ and $850{ }^{\circ} \mathrm{C}$, respectively. After hot rolling, the strips were cooled to $690-700{ }^{\circ} \mathrm{C}$ by water, followed by air cooling for $20 \mathrm{~s}$, and cooled by water again to $150{ }^{\circ} \mathrm{C}$ on the run-out table, and then placed in the coil box to simulate the industrial coiling process.
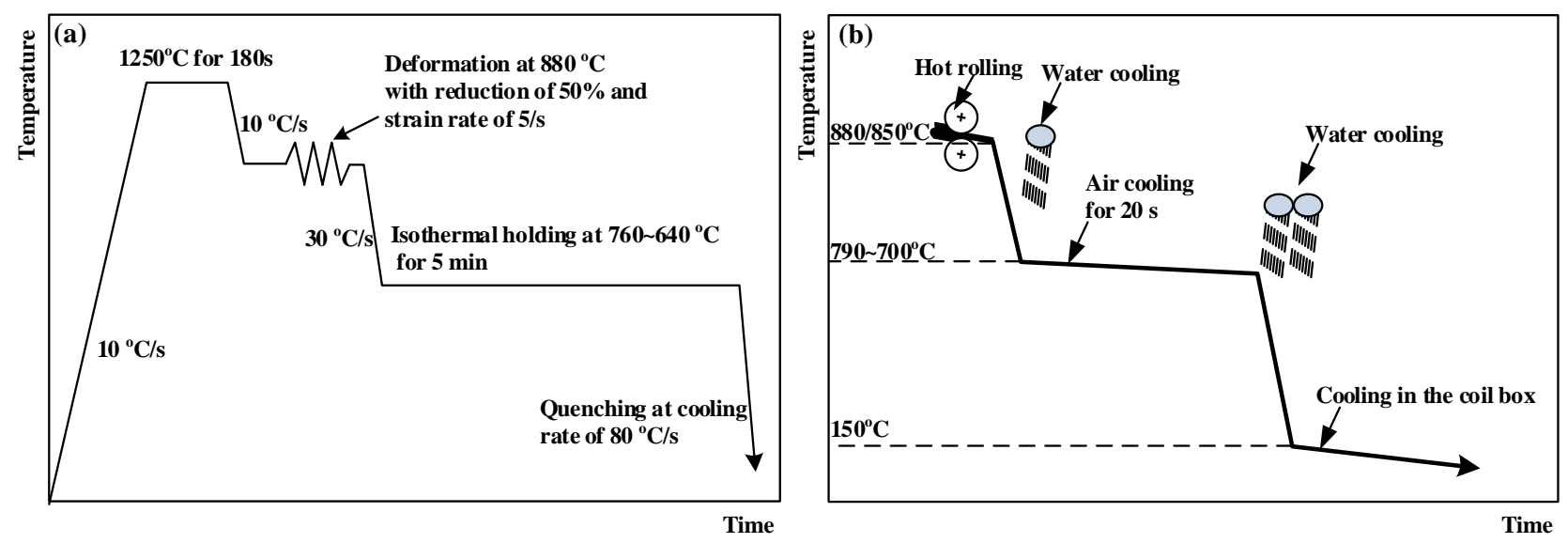

Fig. 1 Schematic diagrams of the experimental process: (a) TMCP simulation and (b) TMCP practice.

\subsection{Microstructure and mechanical properties}

Specimens for optical microscopy were prepared from thermally simulated samples and hot rolled strips using regular grinding, polishing, and etching in $4 \%$ nital solution for $10 \mathrm{~s}$. To accurately measure the volume fraction of martensite, another set of metallographic specimens were etched with LaPera etchant for $60 \mathrm{~s}$ [20]. The microstructure was observed by Leica-DMIRM optical microscope. Transmission electron microscopy specimens with diameter of $3 \mathrm{~mm}$ and thickness of $50 \mu \mathrm{m}$ were twin-jet electropolished in a solution containing $9 \%$ perchloric acid and $91 \%$ ethylalcohol at $-30^{\circ} \mathrm{C}$, at a voltage of $30 \mathrm{~V}$. They were examined by field-emssion transmission electron microscopy (FEI Tecnai $\mathrm{G}^{2}$ F20), operated at $200 \mathrm{kV}$. The energy dispersive X-ray spectroscopy (EDS) was used to characterize the chemistry of precipitates.

Microhardness measurements were carried out in individual ferrite grains and martensite islands/blocks 
using FM-700 Vickers hardness testing machine at a load of $10 \mathrm{~g}$. Macrohardness was also determined by universal-hardness testing machine (KB $3000 \mathrm{BVRZ})$ at a load of $10 \mathrm{~kg}$. The tensile samples with gauge of 50 $\mathrm{mm}$ and width of $12.5 \mathrm{~mm}$ were machined from the strips parallel to the rolling direction. The tensile tests were conducted at room temperature using CMT5105-SANS electron universal testing machine at cross-head speed of $3 \mathrm{~mm} / \mathrm{min}$.

\section{Results}

\subsection{Microstructure of hot rolled Ti-bearing dual phase steels at different treatment temperatures}

Fig. 2 shows the microstructure of steels treated at different temperatures. There was a noticeable variation in the fraction of martensite with change in isothermal temperature. When the isothermal temperature was relatively high $\left(740-760{ }^{\circ} \mathrm{C}\right)$, the microstructure was comprised of martensite matrix with volume fraction greater than $70 \%$ and fine ferrite grains. But when the isothermal temperature was decreased to $720-640{ }^{\circ} \mathrm{C}$, the microstructure consisted of ferrite matrix and martensite islands distributed in the matrix, which is the classic microstructure of dual phase steels. Fig. 3 illustrates that the volume fraction of martensite was significantly decreased with decrease in isothermal temperature from $760{ }^{\circ} \mathrm{C}$ to $720{ }^{\circ} \mathrm{C}$, but remained relatively stable $(\sim 7 \%)$ in the range between $680{ }^{\circ} \mathrm{C}$ and $640{ }^{\circ} \mathrm{C}$. The morphology of martensite was characterized by large-size blocks of dimensions $\sim 100-200 \mu \mathrm{m}$ at $760-740{ }^{\circ} \mathrm{C}$, but was finely dispersed islands of size $\sim 5-15 \mu \mathrm{m}$ at temperatures less than $680^{\circ} \mathrm{C}$.



Fig. 2 Optical micrographs of specimens isothermally heat treated at $760{ }^{\circ} \mathrm{C}(\mathrm{a}), 740{ }^{\circ} \mathrm{C}(\mathrm{b}), 720{ }^{\circ} \mathrm{C}(\mathrm{c}), 700{ }^{\circ} \mathrm{C}$ (d), $680{ }^{\circ} \mathrm{C}(\mathrm{e}), 660^{\circ} \mathrm{C}(\mathrm{f})$, and $640{ }^{\circ} \mathrm{C}(\mathrm{g})$. 


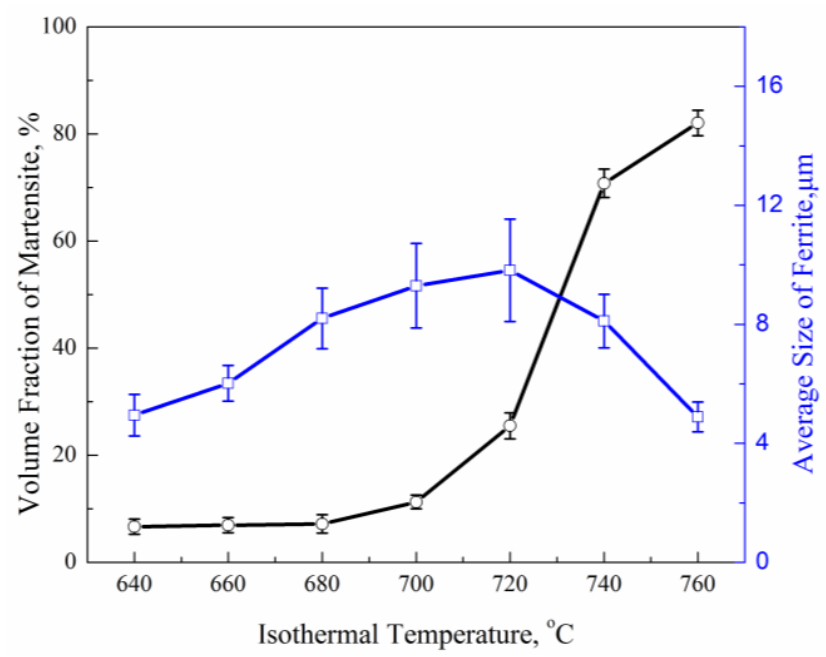

Fig. 3 Martensite volume fraction and average size of ferrite grains with respect to treatment temperature.

The elongated martensitic structure and a small amount of ferrite at prior austenite grain boundaries, allotriomorphic ferrite $\left(\mathrm{F}_{\mathrm{GBA}}\right)$, were observed in Fig. 2a. The elongated martensite implied that the deformed austenite was formed prior to isothermal heat treatment. The deformed austenite was characterized by pancake shape, which means an increase in austenite boundaries and intragranular deformation bands. This increase in prior deformed austenite boundaries and intragranular deformation bands were potential sites for ferrite nucleation, where driving force for nucleation was increased because of the deformation energy. Ferrite mainly nucleated at boundaries at high isothermal heat treatment temperature $\left(760{ }^{\circ} \mathrm{C}\right)$ because of the small undercooling and the recovery of deformed austenite, and was characterized by small size, with average size of $\sim 5 \mu \mathrm{m}$. When the isothermal heat treatment temperature was $740{ }^{\circ} \mathrm{C}$, ferrite nucleation was increased and occurred partly inside the prior deformed austenite (Fig. 2b). When the isothermal heat treatment temperature was less than $720^{\circ} \mathrm{C}$, a number of ferrite were nucleated and the average size was decreased with decrease in isothermal heat treatment temperature (Fig. 3) because of the high undercooling and greater preservation of deformation energy.

\subsection{Precipitation in ferrite matrix at different temperatures}

Specimens subjected to heat treatment at $720^{\circ} \mathrm{C}, 680{ }^{\circ} \mathrm{C}$, and $640{ }^{\circ} \mathrm{C}$, whose ferrite content was greater than martensite, were examined by transmission electron microscopy (TEM). The TEM observations presented in Figs. 4 indicated a high density of nanoscale (less than $10 \mathrm{~nm}$ ) precipitations in the ferrite matrix obtained at $720^{\circ} \mathrm{C}$. According to the EDS analysis, the precipitates were TiC (Fig. 4d and e). It is pertinent to mention that two types of precipitate morphology were observed in the ferrite grains: interphase precipitates, which 
exhibited row-like under TEM, and random precipitates, which were dispersive distribution, as indicated in Fig. 4. Majority nanoscale $\mathrm{TiC}$ interphase precipitates were organized as planar, while some were presented as curved manner (Fig. 4b). It may be seen from Fig. 5 that the morphology of TiC precipitation, especially the interphase, changed with decrease in treatment temperature. It was noted that the observation of curve-pattern interphase precipitates in specimens treated at $680{ }^{\circ} \mathrm{C}$ was more difficult than at $720{ }^{\circ} \mathrm{C}$ on observing by TEM. When the treatment temperature decreased to $640{ }^{\circ} \mathrm{C}$, all the interphase precipitates were presented as planar array with regular row spacing. The row spacing of interphase precipitation was significantly reduced with decrease in treatment temperature. When the treatment temperature was $720{ }^{\circ} \mathrm{C}$, the average row spacing of interphase precipitation was $\sim 56 \mathrm{~nm}$, and reduced to $\sim 34 \mathrm{~nm}$ and $\sim 14 \mathrm{~nm}$ when the temperature was decreased to $680{ }^{\circ} \mathrm{C}$ and $640{ }^{\circ} \mathrm{C}$, respectively. Additionally, it may be seen from Figs. $4 \mathrm{c}, \mathbf{5 d}$ and $\mathrm{f}$ that the density of random precipitates obtained at $640{ }^{\circ} \mathrm{C}$ was significantly higher than those obtained at $720{ }^{\circ} \mathrm{C}$ and $680{ }^{\circ} \mathrm{C}$. When the treatment temperature decreased from $720{ }^{\circ} \mathrm{C}$ to $680{ }^{\circ} \mathrm{C}$ and $640{ }^{\circ} \mathrm{C}$, the average size of precipitates decreased from $5.4 \mathrm{~nm}$ to $4.2 \mathrm{~nm}$ and $2.2 \mathrm{~nm}$. The high density of nanoscale TiC particles obtained at lower treatment temperature can be explained in terms of increased driving force for nucleation. Also, the coarsening of $\mathrm{TiC}$ particles is restrained at lower isothermal temperature. Fig. $\mathbf{6}$ shows the size distribution of TiC particles obtained at treatment temperatures of $720{ }^{\circ} \mathrm{C}, 680{ }^{\circ} \mathrm{C}$ and $640{ }^{\circ} \mathrm{C}$. Approximately 2000 precipitates were measured for their size from each specimen. The size distribution was relatively broad in the specimen treated at $720{ }^{\circ} \mathrm{C}$. The size of majority of the precipitates was in the range of $\sim 1-10 \mathrm{~nm}$ and few precipitates were $~$ $15-20 \mathrm{~nm}$ (less that 1\%). With decrease in heat treatment temperature, the size distribution became narrower and the peak shifted to the small size region. The precipitates size of less than $\sim 3 \mathrm{~nm}$ dominated in the specimen isothermally heat treated at $640{ }^{\circ} \mathrm{C}$, which would significantly contribute to precipitation strengthening. 




Fig. 4 Precipitation in the specimen treated at $720^{\circ} \mathrm{C}$ : (a) precipitation in ferrite matrix, (b) random precipitation, (c) interphase precipitation, and (d) and (e) EDS spectra obtained from matrix and precipitate with size of $15-20 \mathrm{~nm}$.
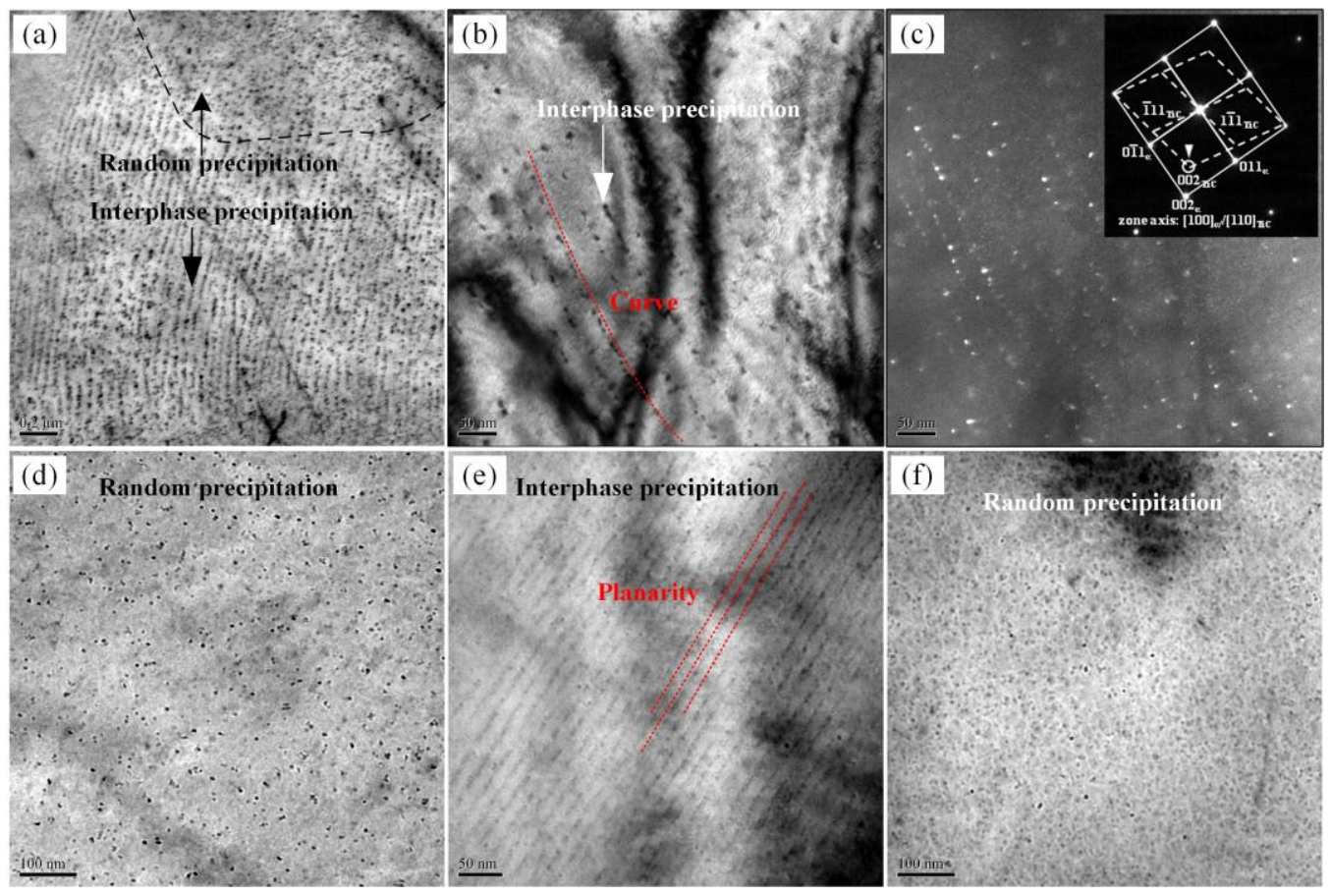

Fig. 5 Precipitation treated at $680{ }^{\circ} \mathrm{C}$ and $640{ }^{\circ} \mathrm{C}$ : (a) precipitation in ferrite matrix obtained at $680{ }^{\circ} \mathrm{C}$, (b) and (c) interphase precipitation obtained at $680{ }^{\circ} \mathrm{C}$ in bright field and dark field obtained from $002_{\mathrm{TiC}}$ position, (d) random precipitation obtained at $680{ }^{\circ} \mathrm{C}$, and (f) and (g) precipitation in ferrite matrix obtained at $640{ }^{\circ} \mathrm{C}$. 

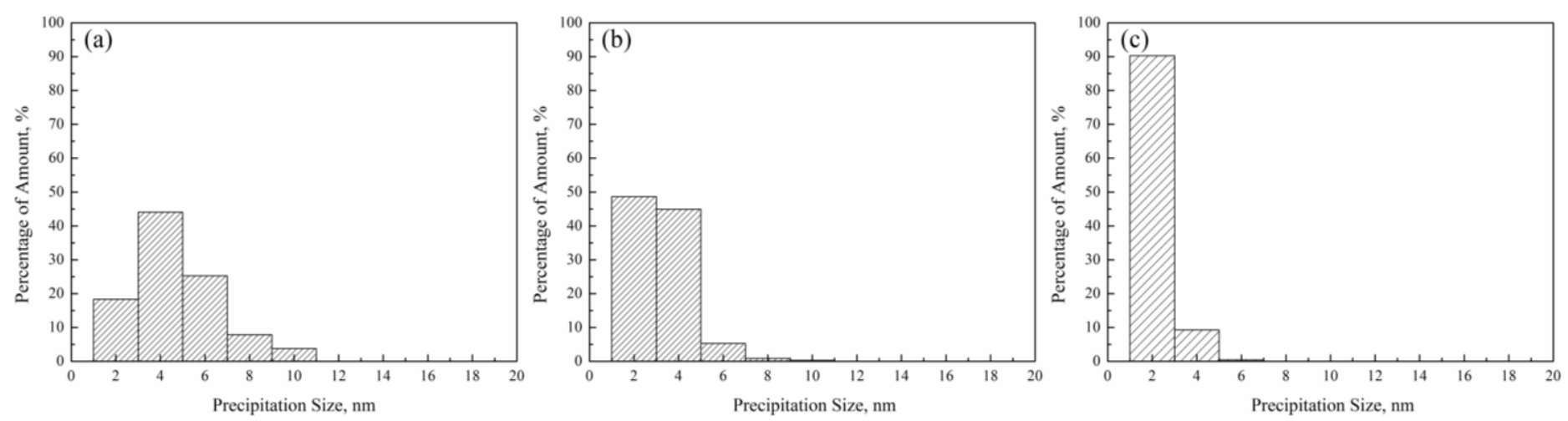

Fig. 6 Size distribution of precipitates obtained at (a) $720{ }^{\circ} \mathrm{C}$, (b) $680{ }^{\circ} \mathrm{C}$ and (c) $640{ }^{\circ} \mathrm{C}$.

3.3 Microstructure, precipitation and mechanical properties of Ti-bearing dual phase steels obtained by TMCP

Microstructure of the Ti-bearing dual phase steels processed via TMCP are presented in Fig. 7. Although the steels mainly consisted of ferrite matrix and martensite, the microstructure was different with respect to the finish rolling temperature. At finish rolling temperature of $880{ }^{\circ} \mathrm{C}$, the microstructure was comprised of ferrite grain with average size of $4.7 \mu \mathrm{m}$ and $34 \%$ martensite. The martensite was lath-like (Fig. $7 b$ ), and a small fraction of bainite were observed inside the large block martensite. In conventional hot rolled dual phase steels, twinned martensite is usually obtained due to high carbon-content dissolved in untransformed austenite after nucleation of ferrite [21]. In Ti-bearing dual phase steel, the precipitation of TiC consumed the dissolved carbon, which may be the reason of formation of lath martensite. When the finish rolling temperature was decreased to $850{ }^{\circ} \mathrm{C}$, the average grain size of ferrite was reduced to $3.5 \mu \mathrm{m}$ and the volume fraction of martensite was reduced to $14 \%$. With decrease in finish rolling temperature, the degree of deformation austenite increases, which means an increase in austenite boundaries, intragranular deformation bands and dislocations, providing more nucleation sites for ferrite transformation. Additionally, the decrease in finish rolling temperature provides greater deformation stored energy that increases the nucleating ability $[22,23]$. Thus, the reduction of finish rolling temperature promoted ferrite grain refinement and increased the volume fraction of ferrite. Fig. $7 d$ shows that the lath width of martensite in steel finish rolled at $850{ }^{\circ} \mathrm{C}$ was smaller than at $880{ }^{\circ} \mathrm{C}$. This may result from the higher volume fraction of austenite-ferrite transformation that promoted greater carbon-enrichment in untransformed austenite. 




Fig. 7 Microstructure of the steels finish rolled at $880{ }^{\circ} \mathrm{C}$ (a) and (b), and $850{ }^{\circ} \mathrm{C}$ (c) and (d).
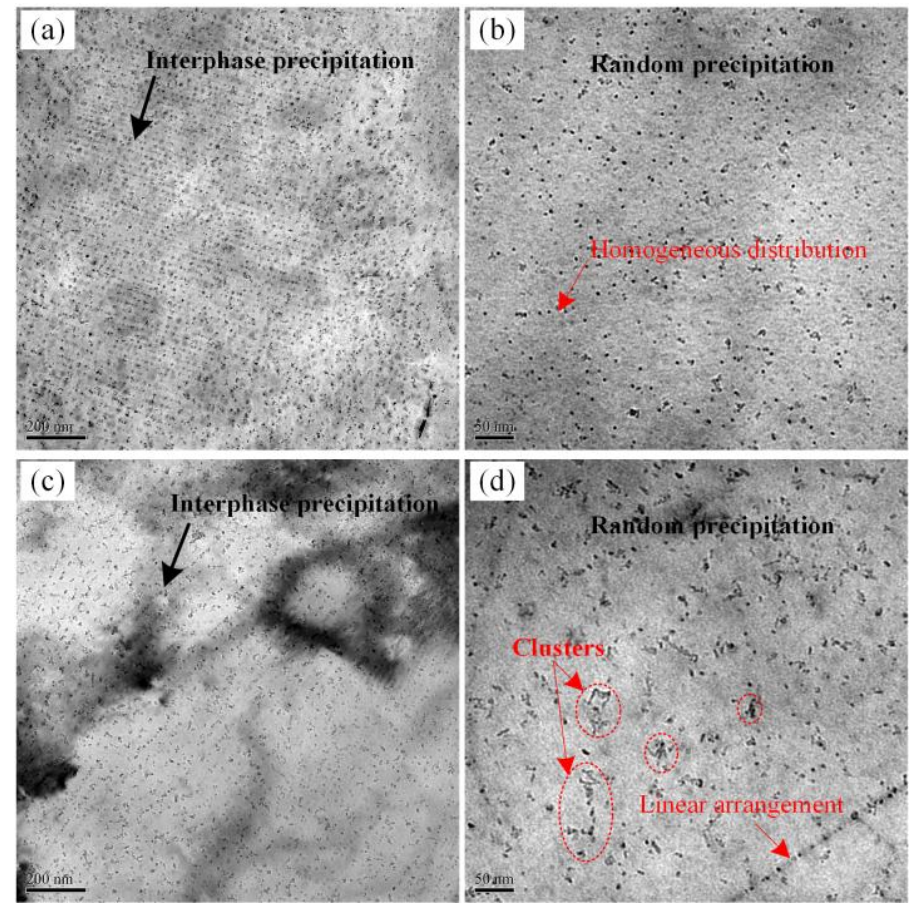

Fig. 8 Precipitation in ferrite matrix of the steels finish rolled at $880{ }^{\circ} \mathrm{C}$ (a) and (b), and $850{ }^{\circ} \mathrm{C}$ (c) and (d).

During observation of precipitation in ferrite matrix by TEM, we noted that both interphase and random precipitation were observed, but the interphase precipitation in steel finish rolled at $880{ }^{\circ} \mathrm{C}$ was more frequent than at $850{ }^{\circ} \mathrm{C}$. The precipitation in the ferrite matrix is shown in Fig. 8. It is seen from Fig. $\mathbf{8 b}$ and d that the distribution of random precipitation was different between the steels finish rolled at $880{ }^{\circ} \mathrm{C}$ and $850{ }^{\circ} \mathrm{C}$. The precipitates in steel finish rolled at $880{ }^{\circ} \mathrm{C}$ were homogeneously distributed in the ferrite matrix and were spherical (Fig. 8b). However, steel finish rolled at $850{ }^{\circ} \mathrm{C}$ precipitated inhomogeneously and some of precipitates presented as vermicular (Fig. 8d). As indicated in Fig. 8d, many of precipitates were presented as clusters or had a linear arrangement.

As shown in Fig. 9, the tensile curves of the two steels exhibited continuous yielding. The yield strength, tensile strength and elongation of the steel finish rolled at $880{ }^{\circ} \mathrm{C}$ were $571 \mathrm{MPa}, 823 \mathrm{MPa}$ and $19 \%$, respectively. When the finish rolling temperature was decreased to $850{ }^{\circ} \mathrm{C}$, the yield strength and tensile 
strength were respectively reduced to $550 \mathrm{MPa}$ and $785 \mathrm{MPa}$, while the elongation was increased to $21 \%$.

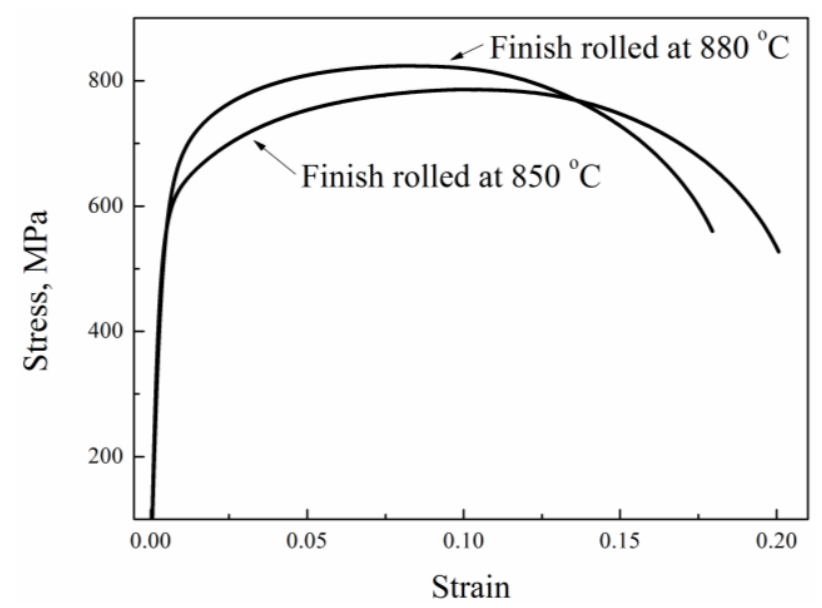

Fig. 9 Stress-strain curves of steels.

\section{Discussion}

\subsection{Precipitation behavior in Ti-bearing hot rolled dual phase steels}

The results of TEM observation indicated that abundant $\mathrm{TiC}$ precipitation were obtained in Ti-bearing dual phase steels subjected to simulation experiment and TMCP (Figs. 4, 5 and 8). The abundant precipitation of TiC in ferrite matrix is attributed to the difference in solid solubility product of $[\mathrm{Ti}][\mathrm{N}]$ and $[\mathrm{Ti}][\mathrm{C}]$ in austenite and ferrite. Fig. 10 shows a comparison of solid solubility formula of [Ti][N] and [Ti][C]. The solid solubility product from high to low follows the sequence $[\mathrm{Ti}][\mathrm{C}]_{\gamma},[\mathrm{Ti}][\mathrm{C}]_{\alpha}$ and $[\mathrm{Ti}][\mathrm{N}]_{\gamma}$. TiN precipitates in austenite at high temperatures because of the low solid solubility product of $[\mathrm{Ti}][\mathrm{N}]_{\gamma}$ and large difference in solid solubility product of $[\mathrm{Ti}][\mathrm{N}]_{\gamma}$ and $[\mathrm{Ti}][\mathrm{C}]_{\gamma}$. As the temperature decreased to the ferrite transformation region, a large number of TiC particles were nucleated as a result of the low solid solubility product of $[\mathrm{Ti}][\mathrm{C}]_{\alpha}$.

In this hot rolled Ti-bearing dual phase steel, both random and interphase precipitation were observed in the same ferrite grain (Figs. 4, 5, and 8). The co-existence of random and interphase precipitation in the same ferrite matrix implies multiple precipitation mechanisms, and is associated with the velocity of austenite/ferrite interface movement. Only if the mobility of $\alpha / \gamma$ interface and the diffusion coefficient of microalloyed atoms are similar, precipitates can nucleate at the moving $\alpha / \gamma$ interface during $\alpha / \gamma$ transformation, forming interphase precipitation [26-31]. If not, the particles nucleate randomly and grow in the ferrite matrix after $\alpha / \gamma$ transformation because of high supersaturation, commonly observed in microalloyed steels. Chen et al. also 
suggested that interphase precipitation occurred in the initial and final transformation stages because of the matching of interface movement velocity and diffusivity of microalloying elements, but is not formed in the intermediate transformation stage, where the interface movement velocity is too high [26,27].

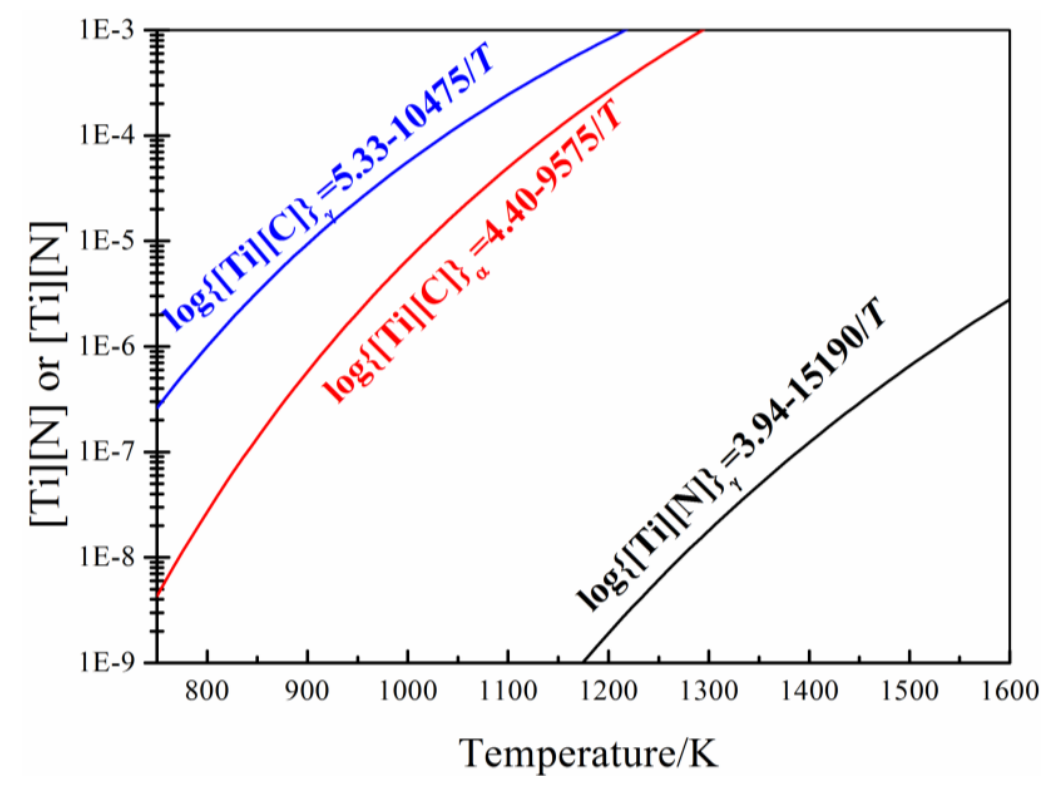

Fig. 10 Solid solubility product of $[\mathrm{Ti}][\mathrm{N}]$ and $[\mathrm{Ti}][\mathrm{C}][24,25]$.

The nucleation mechanism of $\mathrm{TiC}$ interphase precipitation varied with treatment temperature. There are three proposed nucleation mechanisms of $\mathrm{TiC}$ interphase precipitation: ledge, quasi-ledge and bowing mechanisms [27-31]. The ledge mechanism is responsible for planar interphase precipitation with regular row spacing, and the nucleation of precipitates only occurs on the immobile $\alpha / \gamma$ interface with relatively low energy [28]. The TiC interphase precipitates obtained at $640{ }^{\circ} \mathrm{C}$ exhibited planar with regular row spacing (Fig. 5e), implying the ledge mechanism. In some cases, the precipitates can nucleate at the incoherent curved $\alpha / \gamma$ interface with relatively high energy, which can be pinned by a large number of precipitates and bow partially to form a bulge, referred as quasi-ledge mechanism [29]. The curved precipitation can be also formed via bowing mechanism, where the moving $\alpha / \gamma$ interface is pinned by precipitates, then bow forward and bypass the precipitates, and finally becomes a bowed boundary [20]. The observation of curve-pattern of interphase precipitation (Figs. 4b and 5b) implied quasi-ledge or bowing mechanism. Thus, when the treatment temperature increased from $640{ }^{\circ} \mathrm{C}$ to $720^{\circ} \mathrm{C}$, the nucleation mechanism of TiC interphase precipitation was changed from ledge mechanism to quasi-ledge or bowing mechanism.

Hot rolling significantly influences the precipitation behavior. On the one hand, the interphase 
precipitation is inhibited by hot rolling, such that the interphase precipitation was less frequently observed in hot rolled steels, especially the steel with finish rolling temperature of $850{ }^{\circ} \mathrm{C}$, compared to the steel obtained by thermal simulation. The possible reason was that hot rolling increased the ferrite transformation driving force and nucleation rate, leading to rapid movement of austenite/ferrite interface. On the other hand, the random precipitation behavior is also influenced by hot rolling. As mentioned above, the dislocations and dislocation cells were produced by hot rolling and increased with decrease in finish rolling temperature. Dislocations are the disturbed regions with low thermodynamically stability and atoms diffuse easily around dislocations, where $\mathrm{TiC}$ was readily precipitated. Thus, hot rolling at lower temperature resulted in inhomogeneous precipitation, characterized by linear or clustered arrangement (Fig. 8d). These linear or clustered precipitates were considered to precipitate on dislocations and dislocation cells.

\subsection{Effect of precipitation on mechanical properties in hot rolled dual phase steels}

Fig. 11 shows the hardness variation with treatment temperature. It is known that the high strength of conventional dual phase steels is due to the presence of hard martensite phase. However, Fig. 11 indicated that the variation of macrohardness with treatment temperature was consistent with ferrite microhardness, rather than that of martensite microhardness and volume fraction of martensite. Thus, the hardness or strength of the experimental steel was not only governed by martensite but also by ferrite. The strength of dual phase steels obeys the law of mixture or the modified law of mixture [32-35]. The rule of mixture in dual phase steels is given by: $\sigma_{D P}=\sigma_{F} f_{F}+\sigma_{M} f_{M}$, where $\sigma$ and $f$ are the strength and volume fraction of individual phases, respectively; $D P, F$ and $M$ represent dual phase, ferrite phase and martensite phase, respectively. Based on the rule of mixture, it is understandable that the contribution of $\sigma_{F}$ to $\sigma_{d p}$ is greater because of the high content of ferrite phase $\left(f_{F}\right.$ usually 70 95\%). The nanoscale TiC particles significantly increased the strength or hardness of the ferrite matrix $\left(\sigma_{F}\right)$, hence effectively increased the strength of dual phase steel $\left(\sigma_{d p}\right)$. The dependence of strength of Ti-bearing dual phase steels from martensite phase may become less because of the increased contribution to strength from precipitation.

The microhardness of ferrite grains in $0.06 \mathrm{C}-0.45 \mathrm{Si}-1.55 \mathrm{Mn}$ hot rolled dual phase steel was measured to be less than $150 \mathrm{HV}$ [36]. As shown in Fig. 11, the microhardness of ferrite grains in Ti-bearing dual phase steel was greater than $190 \mathrm{HV}$ at treatment temperature range of $720^{-} 640^{\circ} \mathrm{C}$ and was increased with decrease in 
treatment temperature. When the treatment temperature was $640{ }^{\circ} \mathrm{C}$, it was $248 \mathrm{HV}$. The increase in microhardness of ferrite grains reflected the contribution to hardness from nanoscale TiC particles. When the treatment temperature was lowered from $720{ }^{\circ} \mathrm{C}$ to $640{ }^{\circ} \mathrm{C}$, the number density of nanometer-size carbides precipitated in ferrite matrix was increased and the size of carbides was reduced, which increased the microhardness (or strength) via precipitation strengthening. The increment in yield strength of ferrite grains due to nanoscale precipitates can be expressed by Ashby-Orowan relationship [37]:

$$
\Delta \sigma_{\mathrm{y}}=\frac{0.538 G b f^{1 / 2}}{\bar{X}} \ln \frac{\bar{X}}{2 b}
$$

where $\Delta \sigma_{y}$ is the increment of yield strength contributed by precipitation strengthening (MPa); $G$ is the shear modulus (81600MPa in Fe matrix); $b$ is the magnitude of the Burguers vector $(0.248 \mathrm{~nm}) ; f$ is the volume fraction of particles $(0.19 \%$, calculated by Thermo-calc software); $\bar{X}$ is the mean effective particle diameter $(\mathrm{nm})$, considered as the average diameter in this paper. The calculated precipitation strengthening by nanoscale TiC particles treated at $720{ }^{\circ} \mathrm{C}, 680{ }^{\circ} \mathrm{C}$ and $640{ }^{\circ} \mathrm{C}$ were $\sim 220 \mathrm{MPa}, \sim 270 \mathrm{MPa}$ and $\sim 320 \mathrm{MPa}$, respectively.

The hardness ratio between ferrite and martensite was $\sim 0.43$ in hot rolled plain C-Mn dual phase steels [36], while that in this hot rolled Ti-bearing dual phase steel was 0.49 at treatment temperature of $720{ }^{\circ} \mathrm{C}$ because of precipitation strengthening by nanoscale $\mathrm{TiC}$ particles. As shown in Fig. 11, although the microhardness was increased form $190 \mathrm{HV}$ to $220 \mathrm{HV}$ with the treatment temperature decreasing from $720{ }^{\circ} \mathrm{C}$ to $680{ }^{\circ} \mathrm{C}$, the hardness ratio between ferrite and martensite was relatively constant. Besides microhardness of ferrite, hardness ratio is also determined by the microhardness of martensite, which depends on the carbon content in martensite. During transformation from austenite to ferrite, the untransformed austenite is enriched with carbon that subsequently transforms into martensite. The carbon content in martensite was increased with decrease in the volume fraction of martensite. When the treatment temperature decreased from $720{ }^{\circ} \mathrm{C}$ to $680{ }^{\circ} \mathrm{C}$, the volume fraction of martensite was decreased, such that there was an increase in martensite hardness. Although the volume fraction of martensite remained relatively constant at $\sim 7 \%$ in the temperature of $680 \sim 640$ ${ }^{\circ} \mathrm{C}$, the hardness of martensite was decreased. The possible reason was slow diffusion of carbon at lower temperature led to the reduction of carbon enrichment in martensite. Thus, when the treatment temperature was decreased from $680{ }^{\circ} \mathrm{C}$ to $640{ }^{\circ} \mathrm{C}$, the hardness ratio increased from 0.49 to 0.66 , because of the decrease in martensite hardness and the increase in ferrite hardness strengthened by nanoscale TiC particles. 
In conventional dual phase steels without precipitation in ferrite, the low yield strength is attributed to the soft ferrite matrix. Compared with the conventional dual phase steels, the hot rolled Ti-bearing dual phase steels had higher yield strength (greater than $550 \mathrm{MPa}$ ) and yield ratio (greater than 0.69) because the ferrite matrix was effectively strengthened by nanoscale Ti particles. Fig. 9 indicated that the tensile strength of hot rolled Ti-bearing dual phase steels was decreased with the reduction of finish rolling temperature. In Fe-Mn-C dual phase steel, the tensile strength was mainly governed by the hard martensite, and the contribution of martensite to tensile strength can be estimated by $16.3 \times$ pct martensite [33]. In this case, when the martensite volume fraction reduced to $14 \%$ (steel finish rolled at $850{ }^{\circ} \mathrm{C}$ ) from $33 \%$ (steel finish rolled at $880{ }^{\circ} \mathrm{C}$ ), the decrease in tensile strength was estimated to be $\sim 300 \mathrm{MPa}$. However, the decrease in tensile strength of experimental steel was only $\sim 38 \mathrm{MPa}$. The estimated value of grain refinement in steel finish rolled at $850{ }^{\circ} \mathrm{C}$ was higher by $\sim 20$ $\mathrm{MPa}$ than at $880{ }^{\circ} \mathrm{C}$, which was calculated through $8.39 \mathrm{MPa} / d^{-1 / 2}$ (with $d$ being the grain diameter in $\mathrm{mm}$ ) [38]. Even on subtracting the contribution of grain refinement, the experimental decrease in tensile strength was far less than the estimated value according to the reduction of martensite content, which implied that the contribution to tensile strength also comes from other strengthening mechanism, i.e. precipitation strengthening. Thus, the strength of hot rolled dual phase steels was less dependent on martensite content by introducing nanoscale TiC particles in the ferrite matrix. Based on this concept, the volume fraction of martensite can be reduced for a certain grades of dual phase steels, making them more conducive to the formability.

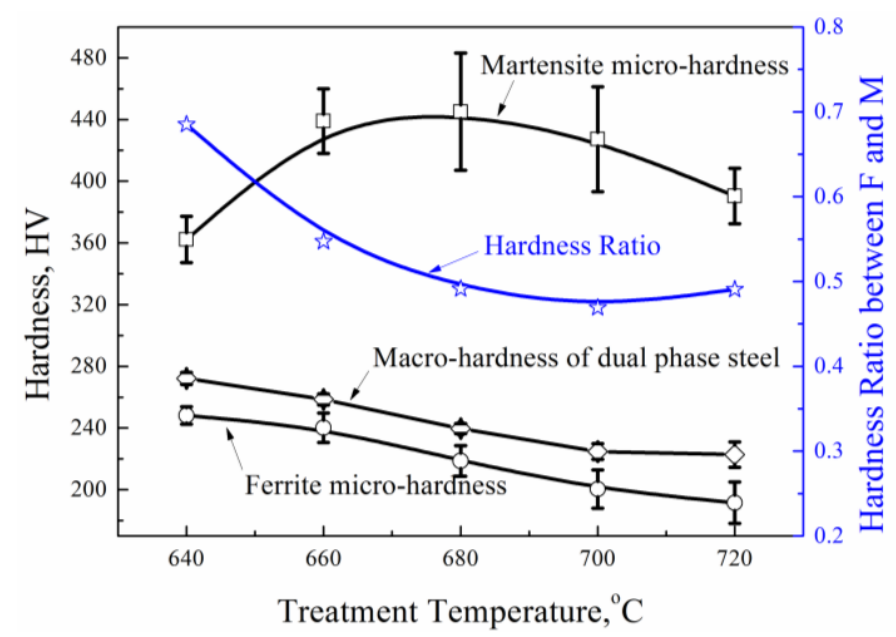

Fig. 11 Hardness and hardness ratio of the experimental steels.

\section{Conclusions}

The microstructural evolution, precipitation behavior, and mechanical properties of a hot rolled Ti-bearing 
dual phase steel with low Si content was studied. The primary conclusions are:

1. The hot rolled Ti-bearing dual phase steels with variation in martensite volume fraction were obtained through change in treatment temperature $\left(760{ }^{\circ} \mathrm{C}\right.$ to $\left.640{ }^{\circ} \mathrm{C}\right)$. When the treatment temperature was between $760{ }^{\circ} \mathrm{C}$ and $740{ }^{\circ} \mathrm{C}$, the microstructure consisted of allotriomorphic ferrite grains and more than $70 \%$ martensite blocks. At treatment temperature less than $720{ }^{\circ} \mathrm{C}$, the microstructure was comprised of ferrite matrix and less than $25 \%$ dispersed martensite islands, which was the typical microstructure of dual phase steels. In TMCP practice, the ferrite grain size and the martensite content were significantly decreased by lowering the finish rolling temperature.

2. Both random precipitation and interphase precipitation with high density of nanoscale TiC particles were observed in the ferrite matrix at the treatment temperature of $640-720^{\circ} \mathrm{C}$. When the treatment temperature decreased from $720{ }^{\circ} \mathrm{C}$ to $640{ }^{\circ} \mathrm{C}$, the average size of precipitates was reduced from $5.4 \mathrm{~nm}$ to $2.2 \mathrm{~nm}$, and the morphology of interphase precipitation was altered from curved to planar and is attributed to the change in nucleation mechanism of TiC interphase precipitation. Additionally, hot rolling inhibited interphase precipitation. With decrease in finish rolling temperature, the precipitation occurred inhomogeneously on dislocations and dislocation cells.

3. The nanoscale TiC particles significantly increased the microhardness of ferrite, and further led to the increase in macrohardness and consequent reduction in hardness difference between ferrite matrix and martensite. The strength of dual phase steels was less dependent on martensite content by introducing precipitation of nanoscale $\mathrm{TiC}$ in ferrite matrix, which provided an approach to reduce the martensite content for a certain grades of dual phase steels. The hot rolled dual phase steels with yield strength of $550 \mathrm{MPa}$, tensile strength of $785 \mathrm{MPa}$ and elongation of $21 \%$ was obtained, involving a number of strengthening mechanisms, transformation strengthening (martensite transformation), precipitation strengthening and grain refinement.

4. This finding proposed an economic and effective approach to improve the strength of hot rolled steels through applying several strengthening mechanisms. However, the accurate contribution of each strengthening mechanism and their relationships with each other are worth further studying to optimize the mechanical properties. Additionally, other mechanical properties of this new dual phase steel, such as toughness and hole expansibility, which are relevant to the application of this steel, still need to be further 
investigated.

\section{Acknowledgements}

This work was financially supported by the National Science Foundation of China (51234002) and Fundamental Research Funds for the Central Universities (N130407001). RDK Misra gratefully acknowledges support from the University of Texas at El Paso, USA. 


\section{References}

1) Y. X. Li, Z. Q. Lin, A. Q Jiang, G. L. Chen, Use of high strength steel sheet for lightweight and crashworthy car body, Mater. Des. 24 (2003) 177-182.

2) R. D. K. Misra, G. C. Weatherly, J. E. Hartmann, A. J. Boucek, Ultrahigh strength hot rolled microalloyed steels: microstructural aspects of development, Mater. Sci. Technol. 17 (2001) 1119-1129.

3) H. L. Yi, Z. Y. Liu, G. D. Wang, D. Wu, Development of Ti-Microalloyed 600 MPa Hot Rolled High Strength Steel J. Iron Steel Res. Int. 17 (2010) 54-64.

4) M. Tanniru, S. Shanmugam, R. D. K. Misra, D. Panda, S. Jansto, Microalloyed V-Nb-Ti and V steels - Part 1 - Stereological study of ferrite-pearlite microstructure and its relationship to toughness, Mater. Sci. Technol. 21 (2005) 159-164.

5) G. Jha, S. Das, S. Sinha, A. Lodh, A. Haldar, Design and development of precipitate strengthened advanced high strength steel for automotive application, Mater. Sci. Eng. A 561 (2013) 394-402.

6) K. Seto, Y. Funakawa, S. Kaneko, Hot rolled high strength steels for suspension and chassis parts “NANOHITEN” and “BHT® Steel”, JFE Technical Report 10 (2007) 19-25.

7) R. Kuziak, R. Kawalla, S. Waengler, Advanced high strength steels for automotive industry: a review Arcn. Civ. Mech. Eng. 8 (2008) 103-117.

8) M. Sarwar, R. Priestner, Influence of ferrite-martensite microstructural morphology on tensile properties of dual-phase steel, J. Mater. Sci. 31 (1996), 2091-2095.

9) S. Oliver, T. B. Jones, G. Fourlaris, Dual phase versus TRIP strip steels: Microstructural changes as a consequence of quasi-static and dynamic tensile testing Mater. Charact. 58 (2007) 390-400.

10) A. Bag, K. K. Ray, E. S. Dwarakadasa, Influence of martensite content and morphology on tensile and impact properties of high-martensite dual-phase steels, Metall. Mater. Trans. A. 30 (1999) 1193-1202.

11) K. Kamibayashi, Y. Tanabe, Y. Takemoto, L. Shimizu, T. Senuma, Influence of Ti and Nb on the strength-ductility-hole expansion ratio balance of hot-rolled low-carbon high-strength steel sheets, ISIJ Int. 52 (2012) 151-157. 
12) K. Hasegawa, K. Kawamura, T. Urabe, Y. Hosoya, Effects of microstructure on stretch-flange-formability of $980 \mathrm{MPa}$ grade cold-rolled ultra high strength steel sheets ISIJ Int. 44 (2004) 603-609.

13) T. Senuma, Physical metallurgy of modern high strength steel sheets ISIJ Int. 41 (2001) 520-532.

14) T. Senuma, Present status of and future prospects for precipitation research in the steel industry ISIJ Int. 42 (2002) 1-12.

15) T. Murakami, M. Kinefuchi, M. Nomura, Y. Mukai, Effects of hot rolling conditions on the fatigue limit of Ti added dual phase hot-rolled steel sheets, J. Jpn. Inst. Met. 72 (2008) 832-838.

16) J. Hu, L. X. Du, J. J. Wang, C. R. Gao, T. Z. Yang, A. Y. Wang, R. D. K Misra, Microstructures and mechanical properties of a new as-hot-rolled high-strength DP steel subjected to different cooling schedules, Metall. Mater. Trans. A. 44 (2013), 4937-4947.

17) W. Bleck, D. Homberg, U. Prahl, P. Suwanpinij, N. Togobytska, Optimal control of a cooling line for production of hot rolled dual phase steel, Steel Res. Int. 85(2014) 1328-1333.

18) C. N. Li, F. Q. Ji, G. Yuan, J. G Wang, D. S. Ren, G. D. Wang, Microstructure and mechanical properties of economical dual phase wheel steels based on CSP line with later ultra fast cooling, Mater. Res. Innovations 19(2015) 85-91.

19) Ouchi C, Sampei T, Kozasu I. The effect of hot rolling condition and chemical composition on the onset temperature of gamma-alpha transformation after hot rolling. Trans ISIJ 1982: 214-222.

20) F. S. LePera, Improved etching technique for the determination of percent martensite in high-strength dual-phase steels, Metallography 12 (1979) 263-368.

21) C. N. Li, F. Q. Ji, G. Yuan, J. Kang, R. D. K. Misra, G. D. Wang, The impact of thermo-mechanical controlled processing on structure- property relationship and strain hardening behavior in dual-phase steels, Mater. Sci. Eng. A 662 (2016) 100-110.

22) Z. L Mi, H. T. Jiang, Z. C. Li, M. F. Chen, Z. G. Wang, Effect of finishing rolling temperature on microstructure and mechanical properties of microalloyed trip steels, J. Iron Steel Res. Int. 20 (2013) 75-80.

23) F. Q. Ji, C. N. Li, S. Tang, G. Yuan, G. D. Wang, Microstructural characteristics with various 
finish rolling temperature and low temperature toughness in hot rolled $\mathrm{Nb}$ - Ti ferritic steel, ISIJ Int. 56(2016) 602-609.

24) K. Natita, Physical chemistry of the groups $\mathrm{IVa}(\mathrm{Ti}, \mathrm{Zr}), \mathrm{V}(\mathrm{V}, \mathrm{Nb}, \mathrm{Ta})$ and the rare earth elements in steel, Trans. ISIJ, 15 (1975) 145-152.

25) K. A. Tailor, Solubility products for Titanium-, Vanadium-, and Niobium-Carbides in ferrite, Scripta. Metall. Mater. 32 (1995) 7-12.

26) C. Y. Chen, C. C. Chen, J. R. Yang, Dualism of precipitation morphology in high strength low alloy steel, Mater. Sci. Eng. A 626 (2015) 74-79.

27) C. Y. Chen, S. F. Chen, C. C. Chen, J. R. Yang, Control of precipitation morphology in the novel HSLA steel, Mater. Sci. Eng. A 634 (2015) 123-133.

28) R. W. K. Honeycombe, Transformation from austenite in alloy-steels, Metall. Trans. A 7 (1976) 915-936.

29) R. A. Ricks, P. R. Howell, The formation of discrete precipitate dispersion on mobile interpahse boundaries in iron-alloys, Acta. Metall., 31 (1983) 853-861.

30) R. A. Ricks, P. R. Howell, Bowing mechanism for interphase boundary migration in alloy-steels, Metal. Sci. 16 (1982) 317-321.

31) H. W. Yen, C. Y. Chen, T. Y. Wang, C. Y. Huang, J. R. Yang, .Orientation relationship transition of nanometre sized interphase precipitated TiC carbides in Ti bearing steel, Mater. Sci. Technol., 26 (2010) 421-430.

32) R. G. Davies, The mechanical properties of zero-carbon ferrite-plus-martensite structures, Metall. Mater. Trans. A 9 (1978) 51-455.

33) R. G. Davies, Influence of martensite composition and content on the properties of dual phase steels, Metall. Mater. Trans. A 9 (1978) 671-679.

34) S. Kuang, Y. L. Kang, H. Yu, R. D. Liu, Stress-strain partitioning analysis of constituent phases in dual phase steel based on themodified law of mixture, Int. J. Min. Met. Mater. 26 (2009) 393-398.

35) E. Ahmad, Modified law of mixture to describe the tensile deformation behavior of thermo mechanically processed dual-phase steel, J. Mater. Eng. Perform. 22 (2013) 2161-2167. 
36) C. N. Li, G. Yuan, F. Q. Ji, D. S. Ren, G. D. Wang, Effects of auto-tempering on microstructure and mechanical properties in hot rolled plain C-Mn dual phase steels, Mater. Sci. Eng. A 665 (2016) 98-107.

37) Gladman T. Precipitation hardening in metals. Mater. Sci. Technol. 15 (1999) 30-36.

38) M. Calcagnotto, D. Ponge, D. Raabe, Effect of grain refinement to $1 \mu \mathrm{m}$ on strength and toughness of dual-phase steels, Mater. Sci. Eng. A 665 (2010) 7832-7840. 